\title{
ANALISA BETA KAROTEN PADA SAYURAN LOKAL DI INDONESIA
}

\author{
Afrinia Eka Sari ${ }^{1 *}$,Elfira Mayasari ${ }^{2}$ \\ 1. Program Studi S1 Ilmu Gizi STIKes Mitra Keluarga, Bekasi-Indonesia \\ 2. Program Studi DIII Analis Kesehatan STIKes Mitra Keluarga, Bekasi-Indonesia
}

*Korespondensi: Afrinia Eka Sari | STIKes Mitra Keluarga | $\underline{\text { afrinia nutri@yahoo.com }}$

\begin{abstract}
Abstrak
Pendahuluan: Potensi sayuran sebagai antioksidan sangat besar mengingat sayur termasuk kedalam menu utama makan yang dikonsumsi setiap hari. Antioksidan memiliki fungsi untuk mencegah terbentuknya radikal bebas yang terjadi akibat pencemaran atau polusi.

Metode: Penelitian ini dilakukan untuk menganalisa kandungan beta karoten pada sayuran lokal di Indonesia dengan cara kuantitaif menggunakkan alat spektrofotometri dengan panjang gelombang 350 - $550 \mathrm{~nm}$. Sampel yang digunakan adalah wortel, labu kuning, bayam merah, jagung, kol ungu, terong ungu, bit merah, cabai merah, tomat dan bayam. Pengukuran sampel dibandingkan dengan standar beta karoten murni, pengukuran dilakukan triplo.

Hasil: Pengukuran seri larutan standar beta karoten dimulai dari konsentrasi 1,5 ppm, 3 ppm dan 5 ppm diperoleh R $=0.985$.

Kesimpulan: Dari hasil pengukuran sampel diperoleh bahwa urutan kandungan beta karoten dari yang tertinngi adalah cabai merah, wortel, jagung manis, bayam merah, labu kuning, tomat, bayam hijau, bit merah, kentang, terong ungu.
\end{abstract}

Kata Kunci : Beta karoten, Sayuran, Spektrofotometri

Diterima 07 November 2018; Accepted 30 Desember 2018

\section{PENDAHULUAN}

Potensi sayuran sebagai antioksidan sangat besar mengingat sayur termasuk kedalam menu utama makan yang dikonsumsi setiap hari. Antioksidan memiliki fungsi untuk mencegah terbentuknya radikal bebas yang terjadi akibat pencemaran atau polusi. Salah satu bentuk antioksidan yang terdapat pada sayuran lokal adalah Beta karoten, Kandungan Beta karoten umumnya dihubungkan dengan kandungan vitamin A pada bahan makanan.

Beta karoten merupakan salah satu jenis karotenoid yang umumnya ditemukan pada sayuran yang berwarna merah atau kuning. Karoten memiliki keunggulan terhadap panas tetapi belum dapat dipastikan apabila sayuran tersebut telah mengalami pemasakan. Karoten dapat disimpan dalam bentuk provitamin A dan akan diubah menjadi vitamin A sesuai kebutuhan (Astawan, 2008: 85-86).

Pada produk pangan karoten ditambahkan pada produk minyak goreng, margarin atau mentega dengan tujuan untuk memberikan warna juga sebagai antioksidan untuk mencegah kandungan lemak teroksidasi.

Beta karoten merupakan komponen yang paling penting dalam makanan yang berwarna jingga. Beta karoten terdiri atas dua grup retinil, yang di dalam mukosa usus kecil akan dipecah oleh enzim beta karoten dioksigenase menjadi retinol, yaitu sebuah bentuk aktif dari vitamin A. B. Beta karoten memberikan pengaruh pada penurunan kolesterol dimana aktivitas beta karoten dapat mencegah terjadinya plak/timbunan kolesterol di dalam pembuluh darah (Astawan M, 2008). Beta karoten dikatakan memiliki fungsi sebagai scavenger radikal bebas dimana beta karoten melindungi membran lipid dari reaksi peroksidasi dan sekaligus menghentikan reaksi rantai dari radikal bebas (Adrianta KA, 2013)

\section{METODE}

Penelitian ini dilaksanakan di laboratorium kimia Analitik, Prodi DIII Analis Kesehatan, STikes Mitra Keluarga. Penelitian ini direncanakan akan berlangsung pada minggu ke 3 bulan Mei sampai dengan bulan Juni 2016.

Prosedur Kerja:

\section{Alat}

Sentrifuge, penyaring filtrat, erlenmeyer, labu ukur, sendok pengaduk, pipet gondok, spektrofotometri UV VIS, gelas kimia, gelas ukur dan pipet tetes.

\section{Bahan}


Sayuran terdiri dari wortel, labu kuning, bayam merah, jagung, kol ungu, terong ungu, bit merah, cabai merah, tomat dan bayam. Bahan kimia yang digunakan adalah aseton, kloroform p.a, heksan p.a, $\beta-$ karoten p.a (sigma) dan etanol absolute p.a.

1. Penetapan Operating time

Larutan baku $\beta$-karoten $50 \mu \mathrm{g} / \mathrm{mL}$ dibaca serapannya pada panjang gelombang $452 \mathrm{~nm}$ sampai diperoleh waktu serapan yang stabil.

2. Penetapan panjang gelombang serapan maksimum.

Larutan baku $\beta$-karoten $50 \mu \mathrm{g} / \mathrm{mL}$ dibaca serapannya pada panjang gelombang $350-550 \mathrm{~nm}$.

3. Penentuan kurva baku

Penentuan kurva baku dibuat seri larutan baku $\beta$ - karoten $50 \mu \mathrm{g} / \mathrm{mL}$ yaitu $3.0 \mu \mathrm{g} / \mathrm{mL}, 6,0 \mu \mathrm{g} / \mathrm{mL}, 9,0$

$\mu \mathrm{g} / \mathrm{mL}, 12 \mu \mathrm{g} / \mathrm{mL}$

C. Uji Kuantitatif beta karoten

Pembuatan larutan baku beta karoten

1. Pembuatan larutan baku dibuat dengan menimbang seksama beta karoten standar dilarutkan dengan kloroform hingga diperoleh konsentrasi larutan induk sebesar $1 \mathrm{mg} / \mathrm{mL}$.

2. Penetapan panjang gelombang serapan maksimum

3. Larutan baku $\beta$-karoten $3 \mu \mathrm{g} / \mathrm{mL}$ dibaca serapannya pada panjang gelombang $350-550 \mathrm{~nm}$.

4. Penentuan kurva baku

5. Penentuan kurva baku dibuat seri larutan baku dari beta karoten $50 \mu \mathrm{g} / \mathrm{mL}$ yaitu 0,$0 ; 1,5 ; 3,0$; dan 5,0 $\mu \mathrm{g} / \mathrm{mL}$, dibaca pada panjang gelombang serapan maksimum yang diperoleh.

\section{HASIL}

Panjang gelombang serapan maksimum dalam penentuan beta karoten pada konsentrasi $50 \mu \mathrm{g} / \mathrm{mL}$ adalah 452,4 nm. Panjang gelombang serapan maksimum yang diukur pada konsentrasi $3 \mu \mathrm{g} / \mathrm{mL}$ adalah $450 \mathrm{~nm}$ dengan range panjang gelombang $350-550 \mathrm{~nm}$. Range tersebut menunjukkan warna yang tampak pada beta karoten yaitu kuning - orange.

Gambar 1. Kurva Panjang Gelombang SerapanMaksimum $\beta$ karoten

Absorban (A)

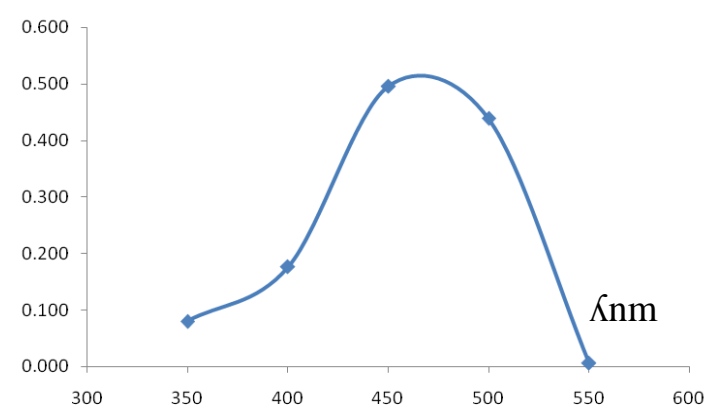

Berdasarkan gambar diatas, panjang gelombang serapan maksimum yang didapat adalah $450 \mathrm{~nm}$, selanjutnya digunakan untuk penentuan kurva standar dengan masing - masing konsentrasi yang telah ditentukan.

Untuk menentukan kurva standar beta karoten dilakukan dengan analisa kuantitatif Penetapan kurva standar beta karoten sangat diperlukan untuk menentukan kadar beta karoten yang lebih tepat dengan alat Spektrofotometer UV-VIS (Labo). Panjang gelombang serapan maksimum adalah $450 \mathrm{~nm}$. Hasil pengukuran kurva baku disajikan pada tabel 1 .

Tabel 1. Serapan larutan beta karoten standar pada beberapa konsentrasi

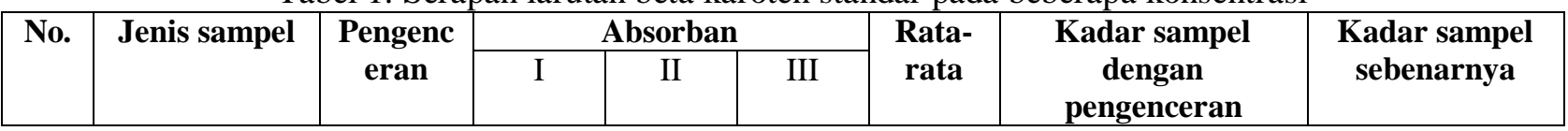


DOI: $10.47522 /$ jmk.v1i1.5

\begin{tabular}{|c|c|c|c|c|c|c|c|c|}
\hline 1 & Wortel & 10 & 0.76 & 0.719 & 0.757 & 0.745 & 3.91 & 39.15 \\
\hline 2 & Labu kuning & 10 & 0.095 & 0.096 & 0.096 & 0.096 & 0.58 & 5.83 \\
\hline 3 & Tomat & 10 & 0.073 & 0.074 & 0.075 & 0.074 & 0.47 & 4.72 \\
\hline 4 & Jagung & 10 & 0.158 & 0.159 & 0.158 & 0.158 & 0.90 & 9.04 \\
\hline 5 & Terong ungu & 10 & -0.004 & -0.004 & -0.004 & -0.004 & 0.07 & 0.72 \\
\hline 6 & Bayam hijau & 10 & 0.053 & 0.054 & 0.054 & 0.054 & 0.37 & 3.68 \\
\hline 7 & Bayam merah & 10 & 0.135 & 0.135 & 0.136 & 0.135 & 0.79 & 7.86 \\
\hline 8 & Bit merah & 10 & -0.003 & -0.002 & -0.002 & -0.002 & 0.08 & 0.80 \\
\hline 9 & kentang & 10 & -0.004 & -0.004 & -0.003 & -0.004 & 0.07 & 0.74 \\
\hline 10 & Cabe merah & 30 & 0.986 & 0.984 & 0.986 & 0.985 & 5.15 & 154.36 \\
\hline
\end{tabular}

Tabel 2. hasil pengukuran absorbansi sample(triplo)

\begin{tabular}{c|c}
\hline $\mathrm{C}(\mu \mathrm{g} / \mathrm{mL})$ & Serapan $(\mathrm{A})$ \\
\hline 0 & 0 \\
1,5 & 0,29 \\
3 & 0,50 \\
5 & 1 \\
\hline
\end{tabular}

\section{PEMBAHASAN}

Pengukuran seri larutan standar beta karoten dimulai dari konsentrasi $1,5 \mathrm{ppm}, 3 \mathrm{ppm}$ dan $5 \mathrm{ppm}$ diperoleh $\mathrm{R}=0.985$ dengan persamaan regresinya: $\mathrm{y}=0.195 \mathrm{x}-0.018$. Untuk melakukan pemeriksaan kandungan beta karoten pada sayuran dilakukan secara random sampling. Sampel diperoleh dari swalayan CAREFOUR dan pasar tradisional rawa lumbu. Tahap awal yang dilakukan adalah melakukan ekstraksi sampel sayuran, tujuan ekstraksi adalah untuk memindahkan senyawa beta karoten yang terkandung dalam sayuran ke dalam larutan heksan : aseton : etanol $=2: 1: 1$. Setelah proses ekstraksi, filtrat disaring dengan corong pisah dan dilakukan pengocokan selama \pm 30 menit yaitu untuk memaksimalkan penarikan beta karoten yang ada pada filtrat sayuran, lalu didiamkan hingga terbentuk 2 fase. Setelah itu, disaring kembali dengan menggunakan kertas saring, kemudian dilakukan pengujian kuantitatif dengan menggunakan Spektrofotometer UV - VIS (Labo)

\section{KESIMPULAN}

Dari hasil pengukuran cabe merah memiliki konsentrasi beta karoten yang paling tinggi dibandingkan jenis sayuran lain yang diukur, urutan selanjutnya dari konsentrasi paling tinggi sampai yang paling rendah setelah cabai merah adalah: wortel $>$ jagung manis $>$ bayam merah $>$ labu kuning $>$ tomat $>$ bayam hijau $>$ bit merah $>$ kentang $>$ terong ungu.

\section{Ucapan Terima Kasih}

Terima kasih kami ucapkan kepada STIKes Mitra Keluarga yang telah memberikan dana hibah PT, serta semua pihak yang telah membantu.

\section{REFERENSI}

Astawan. M dan Andreas L.K 2008. Khasiat Warna-Warni Makanan. Penerbit PT Gramedia. Jakarta.

Gross, Jeana. 1991. Pigments In Vegetables (Chlorophylls and Carotenoids).Van Nostrand Reinhold. New York. 7. 75.

Heriyanto, 2009, Karotenoid (Beta-karoten), (online), (http://repository.usu.ac.id/ bitstream/123456789/20091/4/k arotenoid(beta-karoten).

Hock-Eng, K., Prasad, K. N., Kin-Weng, K., Jiang Y., dan Ismail, A., 2011, Carotenoids and Their Isomers: Color Pigments in Fruits and Vegetables, J. Molc., 16, 1710- 1738. 
Kusharto CM. 2006. Serat Makanan dan Peranannya Bagi Kesehatan. Jurnal Gizi dan Pangan 1 (2), 45-54.

Massey LK, Liebman and SA Kynast. 2005. Ascorbate Increases Human Oxaluria and Kidney Stone Risk. The Journal of Nutrition 135 (7), 1673-1677.

Sinaga S. 2011. Pengaruh Substitusi Tepung Terigu Dan Jenis Penstabil Dalam Pembuatan Cookies Labu Kuning.(Skripsi). Medan. Universitas SumateraUtara.

Stahl, W., Sies, H. 2003. Antioxidant Activity of Carotenoids. Molecular Asfects of Medicine. 24, 345-351.

Vanty, I.R. 2011. Pembuatan dan analisis kandungan gizi Tepung labu kuning (cucurbita moschata duch..). Jurnal sains dan teknik kimia. 